\title{
AVALIAÇÃO DA GENOTOXICIDADE PROVOCADA POR FATORES AMBIENTAIS EM Tradescantia pallida cv purpurea ATRAVÉS DO ENSAIO COMETA
}

\author{
Kerle Aparecida da Silva Leite ${ }^{1}$ \\ Vivian Vieira Zandonato ${ }^{2}$ \\ Antonio Fluminhan ${ }^{3}$
}

RESUMO: Estudos para avaliação da genotoxicidade de agentes com potencial mutagênico têm sido realizados de forma crescente, em decorrência da recente preocupação despertada pelos impactos provocados pelas atividades humanas no meio ambiente. Entre os métodos utilizados para esta avaliação, existem aqueles que determinam as lesões genômicas, que podem resultar em mutação nos diferentes seres vivos, tal como é o caso do ensaio cometa. Na presente pesquisa, foi implantada a metodologia de ensaio cometa para a avaliação de eventuais lesões genômicas provocadas por agentes mutagênicos físicos e químicos sobre a planta Tradescantia pallida cv. purpurea, que é considerada um modelo biológico por excelência para este tipo de avaliação. Amostras de tecidos das folhas desta planta foram coletadas e utilizadas para a avaliação dos dois principais protocolos disponíveis para o teste de ensaio cometa: a versão neutra, que utiliza eletroforese em tampão com $\mathrm{pH}$ neutro, e detecta quebras duplas na molécula de DNA, e a versão alcalina $(\mathrm{pH}>13)$, que foi desenvolvida a partir do método original, e é realizada com o emprego de eletroforese com o pH alcalino e detecta quebras de fita simples e duplas. Inúmeros testes pilotos foram realizados e permitiram, efetivamente, a padronização da metodologia. Os melhores resultados foram obtidos quando os tecidos vegetais sofreram intensa maceração, seguido de alocação criteriosa de reagentes sobre a lâmina microscópica. A implantação da referida metodologia abrirá perspectivas favoráveis para a sua utilização na avaliação do potencial mutagênico de outros fatores antrópicos.

Palavras-chave: Ensaio cometa - Impactos ambientais - Tradescantia pallida cv purpurea

\footnotetext{
${ }^{1}$ Graduada de Ciências Biológicas - Bacharelado, Universidade do Oeste Paulista - UNOESTE. kerle.costa@yahoo.com.br

${ }^{2}$ Graduada de Ciências Biológicas - Bacharelado, Universidade do Oeste Paulista - UNOESTE. vivi.zan@hotmail.com

${ }^{3}$ Professor - Pró-Reitoria de Pesquisa e Pós-graduação, Universidade do Oeste Paulista - UNOESTE. fluminhan@unoeste.br
} 


\section{INTRODUÇÃO}

Estudos para a avaliação da genotoxicidade causada por agentes com potencial mutagênico têm sido realizados de forma crescente. Este crescimento parece ser decorrente da recente preocupação despertada pelos impactos provocados pelas atividades humanas no meio ambiente.

Mudanças provocadas no ambiente podem ser indícios de estresse ou impacto ambiental. As plantas são organismos mundialmente utilizados para o biomonitoramento ambiental, sendo que existe a disponibilidade de uma ampla bibliografia sobre testes de genotoxicidade e mutagenicidade em plantas. A Tradescantia é um gênero de plantas modelos conhecida por serem extremamente sensíveis aos agentes mutagênicos, e que são classificadas como bastante adequadas para o monitoramento in loco das condições ambientais. Espécies deste gênero são utilizadas para a avaliação da mutagenicidade do ar, das águas e de solos, pois elas apresentam apenas seis pares de cromossomos grandes e de fácil observação e, em especial, as células de quase todas as partes da planta desde a ponta da raiz até o tubo polínico em desenvolvimento fornecem materiais excelentes para os estudos citogenéticos (SANTOS, 2004).

Por sua vez, o teste cometa é um teste que detecta danos primários causados no DNA, tais como: quebras de fita simples, duplas ou induzidas por lesões. Este método é um indicativo de mutagenicidade, mesmo considerando que tais lesões podem sofrer reparação pelo sistema de reparo intracelular da espécie. O ensaio cometa pode ser considerado um método simples, rápido, sensível e de baixo custo, e que fornece resultados em nível de células individuais, sendo necessárias amostras celulares extremamente pequenas. A vantagem do teste cometa é que ele pode ser usado para mensurar quebras de DNA em quaisquer tipos de células eucarióticas, não necessariamente em proliferação, sendo necessária apenas uma boa suspensão celular (GREEN et al., 1992; BETTI et al., 1994; ROSS et al., 1995; TICE, 1995; TICE et al., 1996). 


\section{REVISÃO DA LITERATURA}

\subsection{0 ensaio Cometa}

Uma das técnicas mais utilizadas para detecção de genotoxicidade é o teste Cometa (ou, simplesmente, ensaio Cometa - EC), devido à sua capacidade de detectar lesões pré-mutagênicas (KAMMANN et al., 2001). O ensaio Cometa ("Single Cell Gel Electrophoresis") é uma técnica rápida e eficiente quando usada para quantificar as lesões e para detectar os efeitos do reparo no DNA em células individualizadas. O teste consiste em fazer passar uma corrente elétrica pelas células lisadas da amostra em análise, embebidas em gel de agarose de baixo ponto de fusão, sobre lâminas para microscopia (GREEN et al., 1992; BETTI et al., 1994). As células são englobadas em gel e espalhadas sobre uma lâmina e submetidas a uma corrente elétrica que promove uma migração dos segmentos de DNA livres, resultantes de quebras, para fora do núcleo. Após a eletroforese, as células que apresentam núcleo redondo são identificadas como normais, sem dano detectável no DNA. Já as células lesadas são identificadas visualmente por uma espécie de cauda, similar a um cometa, formada pelos fragmentos de DNA que foram "arrastados" pela corrente elétrica da eletroforese.

Nesta metodologia, as análises podem ser realizadas em microscópios ópticos comuns, quando as células são coradas com nitrato de Prata ou corante Giemsa, ou em microscópios de fluorescência, quando coradas com brometo de Etídio ou Acridine Orange, por exemplo. As células são classificadas de acordo com o tamanho da "cauda" com relação a "cabeça" (núcleo), em quatro classes de danos: classe 0: sem cauda, classe 1: cauda com diâmetro menor que a cabeça, classe 3: cauda longa, superior a duas vezes o diâmetro da cabeça, classe 4: cauda longa e espelhada, em forma de leque. Essa metodologia apresenta algumas vantagens sobre os testes bioquímicos e citogenéticos, entre as quais pode-se citar a utilização de um pequeno número de células que não necessariamente estejam em divisão (McKELVEY-MARTIN et al., 1993).

Para alguns autores (TICE et al., 2000), o tamanho da cauda é proporcional à dimensão do dano que foi causado no material genético, mas é de consenso que a simples visualização do "cometa", já significa que variáveis graus de danos estão 
presentes no DNA, podendo envolver: quebras de fitas simples, fitas duplas, cross links, sítios de reparo por excisão e/ou lesões álcali lábeis (SILVA, 2007). Segundo este autor, a identificação do dano no DNA pode ser feita por diferentes maneiras como, por exemplo, medindo-se o comprimento do DNA migrante com a ajuda de uma ocular para mensurações, ou ainda classificando-se visualmente, de acordo com os diferentes níveis de dano, as células analisadas, onde pode-se obter um valor arbitrário que expressa 0 dano geral sofrido por uma população de células.

\subsection{Algumas aplicações comuns do ensaio Cometa}

O ensaio Cometa tem sido utilizado amplamente na genética médica, genética toxicológica ecotoxicológica, em diagnósticos e tratamentos médicos, medicina ambiental, ocupacional, biomonitoramento ambiental, radiação biológica, processos de reparo de DNA (BETTI et al., 1995; COTELLE e FÉRARD, 1999; FAIRBAIRN et al., 1995; GONTIJO e TICE, 2003; VILLELA et al., 2006).

O uso do ensaio Cometa na avaliação dos danos genéticos provocados em alimentos irradiados foi sugerido, inicialmente, por Õstling e Johanson (1984). Cerda et al. (1997) aplicaram este método pela primeira vez em amostras de alimentos. Para simplificar o teste, os autores utilizaram uma camada simples de agarose em vez de uma camada "sanduíche" e, pelo fato das doses de radiação, comumente utilizadas na irradiação de alimentos, causarem danos expressivos no DNA, utilizou um pH neutro em combinação com baixa voltagem e tempo curto de eletroforese. Segundo os referidos autores, o ensaio Cometa pode ser aplicado a um grande número de alimentos tanto de origem animal e vegetal. As vantagens deste teste, no entanto, para alimentos não expostos ao calor são, principalmente, a sua velocidade e simplicidade, visto que a corrida eletroforética demora apenas alguns minutos. O DNA pode ser visualizado mediante coloração com solução de Prata evitando a necessidade de um microscópio de fluorescência, conseqüentemente, este método requer equipamentos relativamente baratos em contraste a outros métodos para identificação de alimentos irradiados (DELINCÉE, 1996; CERDA et al., 1997; CERDA e KOPPEN, 1998). Graças a todos estes desenvolvimentos, hoje, o ensaio Cometa tem 
sido proposto como padrão europeu para a detecção de alimentos irradiados (DELINCÉE, 1996).

Outra aplicação muito comum do ensaio Cometa é para avaliar a genotoxicidade de amostras de águas. Em uma pesquisa desenvolvida por Lau (2002), envolvendo o monitoramento das águas da bacia hidrográfica do rio Guaíba durante dois anos, em vários pontos na área da grande Porto Alegre (RS), foram utilizadas como organismo-modelo as planárias. Observou-se que as amostras dos pontos avaliados apresentaram genotoxicidade significamente superior ao controle negativo. As amostras de água que foram coletadas no inverno tenderam a apresentar genotoxicidade superior do que as amostras avaliadas no verão.

Por sua vez, Ventura (2004) avaliou as diferentes concentrações do herbicida atrazina, que induziram alterações genéticas no organismo-teste Allium cepa, como: anáfases multipolares, pontes, quebras e perdas cromossômicas, micronúcleos, atrasos anafásicos e telofásicos, C-metáfases e prófases com perda de material genético e formação de cometas com caudas mais longas. Essas aberrações sugerem que esse pesticida contenha a característica de ser mutagênico para todas as concentrações testadas naquele estudo.

Em uma outra investigação, Souza (2005) realizou biotestes com o emprego de ensaio Cometa para avaliar o efeito fitocitotóxico do extrato de plantas medicinais nativas do Rio Grande do Sul. O autor relatou que as sementes de cebola podem ser utilizadas para monitorar o efeito de compostos derivados de cumarinas, taninos e terpenos, que são substâncias que no guaco estão presentes em grande quantidade, assim como em: espinheira santa, açoita cavalo e sálvia.

No trabalho realizado por Araújo (2008), dois diferentes métodos de detecção de alimentos irradiados, um biológico (o DEFT/APC), e outro bioquímico (o teste do Cometa) foram aplicados com o objetivo de testar sua aplicabilidade na detecção do tratamento por radiação. Amostras de acelga, agrião, alface da Catalúnia, couve, escarola, espinafre e repolho do comércio varejista foram irradiadas com 0,5kGy e 1,0kGy utilizando um irradiador de ${ }^{60} \mathrm{Co}$. Segundo o autor, o teste do Cometa permitiu distinguir amostras não irradiadas das irradiadas, que mostraram diferentes tipos de cometas decorrentes da fragmentação do DNA. Tanto o método DEFT/APC quanto o teste do Cometa foram 
satisfatoriamente utilizados como métodos de varredura para a detecção do tratamento por irradiação.

$\mathrm{Na}$ pesquisa de Pedro (2008), foram avaliadas as potencialidades tóxicas, citotóxicas, genotóxicas e mutagênicas do inseticida fipronil com bioensaios com Allium cepa, quais suas sementes foram expostas à germinação em fipronil. Os resultados indicaram que o mesmo não apresentou efeito tóxico e citotóxico para a espécie. Este promoveu vários tipos de aberrações cromossômicas, presença de células micro nucleadas, comprovando sua ação genotóxica e mutagênica.

Em um trabalho que teve como objetivo avaliar o efeito foto protetor de espécies de plantas da Antártida, Kappel (2007) investigou a ação do extrato metanólico de cada espécie contra os danos induzidos ao DNA, utilizando a linhagem celular de fibroblasto de pulmão de hamster chinês (células V79) e em uma espécie de molusco utilizando o ensaio Cometa nos animais que foram alimentados com esses vegetais. Segundo o autor, os tratamentos empregados diminuíram significativamente os danos ao DNA induzidos pela UVC em células V79, como verificado pelo ensaio Cometa. Os resultados do ensaio Cometa em células V79 empregando a endonuclease V, demonstraram uma diminuição na formação de dímeros de ciclo butano piridina após a pré-incubação com estes extratos.

\subsection{Variações na metodologia de ensaio Cometa}

Conforme a revisão apresentada por Kappel (2007), existem dois protocolos principais disponíveis para execução do teste, estabelecido de acordo com o pH: a versão neutra conforme o método original de Ostling e Johanson (1984) que utiliza eletroforese em tampão com pH neutro (7-8), detectando quebras duplas nas moléculas de DNA e "cross-links" e a versão alcalina desenvolvida por Singh et al. (1998) a partir do método original , que realiza a eletroforese em tampão alcalino, produzindo assim desnaturação do DNA e detectando quebras de fita única e dupla, sítios álcali-lábeis, ligações cruzadas e sítios de reparação por excisão incompletas.

Entre os princípios que determinam o padrão de formação do cometa, a extensão de migração dos fragmentos de DNA inicialmente aumenta com o dano, porém, atinge um máximo o que é definido pelas condições da eletroforese mas não pelo tamanho 
dos fragmentos (FAIRBAIRN et al., 1995). Virtualmente, todas as células eucarióticas podem ser processadas para analisar o dano no DNA usando o teste do Cometa (FAIRBAIRN et al., 1995; MCKELVEY-MARTIN et al., 1993).

Ressalta-se que o ensaio Cometa não é utilizado para detectar mutações, mas sim lesões genômicas que, após serem processadas, podem resultar em mutação. Diferente das mutações, as lesões detectadas pelo ensaio Cometa são passíveis de correção. Assim sendo, o ensaio Cometa pode ser também utilizado para estudos de reparo do DNA, trazendo informações importantes sobre a cinética e o tipo de lesão reparada, embora não possibilite inferir a fidedignidade do processo de reparo (ALBERTINI et al., 2000).

\section{JUSTIFICATIVAS}

O ensaio Cometa combina a simplicidade da técnica bioquímica de detecção de quebras no DNA com a utilização de poucas células. As vantagens dessa técnica incluem a sensibilidade na detecção de dano no DNA; a coleta de dados em nível de célula individual; o uso de um número pequeno de células para a análise e a possibilidade de aplicação em qualquer população de células eucarióticas; e principalmente a rapidez de resultados.

Tem uma aplicação potencialmente ampla em testes de genotoxicidade in vitro e in vivo, em estudos de dano e reparo no DNA e biomonitoramento humano e ambiental (TICE et al 2000). O ensaio cometa é uma técnica promissora, especialmente diante de agentes químicos. Durante a última década, o ensaio cometa foi extensivamente utilizado como uma ferramenta básica em muitas áreas de pesquisa, alcançando aplicações químicas para biomonitoramento ambiental, radiação biológica, e processos de reparo de DNA e ecotoxicologia genética.

Por sua vez, a utilização de plantas de Tradescantia pallida cv purpurea é plenamente justificada por esta espécie ser extremamente sensível aos diversos tipos de agentes mutagênicos. Estas plantas são classificadas como ideais para o monitoramento in loco das condições ambientais, incluindo-se a radiação solar e a poluição aérea. Numerosos estudos indicam que esta espécie é comumente utilizada para a avaliação da 
mutagenicidade de ar, águas e solos, pois elas apresentam apenas seis pares de cromossomos grandes e de fácil observação e, em especial, as células de quase todas as partes da planta desde a ponta da raiz até o tubo polínico em desenvolvimento fornecem materiais excelentes para os estudos citogenéticos (para uma revisão, veja SANTOS, 2004).

\section{OBJETIVOS}

Este estudo objetivou avaliar a ocorrência de danos genéticos em amostras de tecidos foliares removidos da planta Tradescantia pallida cv. purpurea e que sejam detectáveis através da metodologia de ensaio Cometa Esta pesquisa visou avaliar se os locais onde a planta é cultivada podem oferecer riscos mutagênicos, ou mesmo serem prejudiciais à saúde de outros seres vivos.

A implantação desta metodologia torna possível a avaliação de eventuais lesões genômicas provocadas por agentes mutagênicos físicos (por exemplo: a radiação solar) e químicos (por exemplo: a poluição aérea provocada pelo tráfego de veículos automotores) sobre a espécie vegetal Tradescantia pallida cv. purpurea, que é considerada em modelo biológico por excelência para este tipo de avaliação.

\section{MATERIAIS E MÉTODOS}

\subsection{Materiais biológicos}

Plantas de Tradescantia pallida cv purpurea foram cultivadas em vasos contendo substrato orgânico misturado com solo (proporção 1:1) e submetidas às mesmas condições de cultivo por três meses anteriores ao início dos experimentos, de modo a permitir o pleno desenvolvimento das mesmas.

Amostras de folhas de cada grupo de plantas foram coletadas durante 0 inverno/frio (mês de julho) e durante o calor (mês de outubro), e utilizadas para as análises de ensaio Cometa. 


\subsection{Metodologia do ensaio Cometa}

O teste Cometa foi implantado e padronizado no Laboratório de Citogenômica e Bioinformática da Universidade do Oeste Paulista (UNOESTE) como um protocolo adaptado a partir da metodologia original do método descrito por Singh et al. (1998) e revisado por Tice et al. (2000). Células em suspensão (removidas das folhas das plantas) foram embebidas em $95 \mathrm{ml}$ de agarose com baixo ponto de fusão ("low melting point"). Estas amostras foram colocadas imediatamente sobre a lâmina já coberta com agarose normal. Após a solidificação, as lâminas foram mergulhadas na solução de lise que deve estar gelada (2.5M NaCl, $100 \mathrm{mM}$ EDTA e $10 \mathrm{mM}$ Tris, pH 10.0- 10.5), com adição de $1 \%$ Triton X-100 e 10\% dimetil sulfóxido (DMSO) por no mínimo uma hora e no máximo duas semanas. Posteriormente, as lâminas foram incubadas (dentro da cuba de eletroforese) com tampão de eletroforese (300 mM NaOH e 1 mM EDTA, pH 12.6) por 20 min. Após este período. foi realizada a corrida de eletroforese por 15 min a 25 volts $(0.90 \mathrm{~V} / \mathrm{cm})$ e $300 \mathrm{~mA}$, a uma temperatura de $4^{\circ} \mathrm{C}$. Após a corrida eletroforética cobriu-se as lâminas com solução neutralizadora (com $0.4 \mathrm{M}$ Tris $(\mathrm{pH} 7.5)$. Finalmente, as lâminas foram coradas com solução de Giemsa a 1\% e analisadas em microscópio óptico. Para a visualização do dano no DNA foram analisadas 200 células por amostra.

Em outro protocolo testado, baseado no trabalho realizado por Araújo (2008), foram misturados 90uL da suspensão de células com 600uL de "low melting point" agarose $0,8 \%\left(\mathrm{p} / \mathrm{v} \mathrm{em} \mathrm{H}_{2} \mathrm{O}\right)$ a $45^{\circ} \mathrm{C}$. Desta mistura, 100uL foram rapidamente pipetados sobre uma lâmina com a primeira agarose 1,5\% (utilizada para promover a aderência da segunda camada). As lâminas foram imersas em solução de lise contendo $2,5 \%(\mathrm{p} / \mathrm{v})$ de dodecil sulfato de sódio em $45 \mathrm{mM}$ TBE ( $45 \mathrm{mM}$ Tris base, $45 \mathrm{mM} \mathrm{H}_{3} \mathrm{BO}_{3}$, ImM EDTA, pH 8,4) e incubadas sob agitação lenta por 1 hora a $4^{\circ} \mathrm{C}$. Após uma hora de incubação, as lâminas foram enxaguadas com $\mathrm{H}_{2} \mathrm{O}$ destilada e lavadas por 10 minutos. As lâminas foram imersas na solução de desnaturação $(300 \mathrm{mM} \mathrm{NaOH}$, ImM EDTA, pH>13) e incubadas sob agitação lenta por 20 minutos a $4^{\circ} \mathrm{C}$. As lâminas foram colocadas na câmara de eletroforese preenchida com $45 \mathrm{mM}$ TBE por 10 minutos. A corrida eletroforética foi realizada por 3,5 minutos a $25 \mathrm{~V}$ e $340 \mathrm{~mA}$. Após a corrida, as lâminas foram lavadas com $\mathrm{H}_{2} \mathrm{O}$ destilada por 5 minutos e secas na estufa a $37^{\circ} \mathrm{C}$. As lâminas foram imersas na solução do corante 
Giemsa, a 1\% em PBS, pH 7,4, por 5 minutos e finalmente lavadas com $\mathrm{H}_{2} \mathrm{O}$ destilada por 1 minuto. Foi colocada uma lamínula sobre a lâmina ainda úmida, para posterior observação ao microscópio ótico.

\section{RESULTADOS E DISCUSSÃO}

Foram avaliados os dois principais protocolos disponíveis para o teste de ensaio cometa, que são estabelecidos de acordo com o pH: a versão neutra $(\mathrm{pH} 7-8)$, onde utilizou-se eletroforese em tampão com pH neutro e apropriado para a detecção de quebras duplas na molécula de DNA. Em seguida, foi testada a metodologia em sua versão alcalina $(\mathrm{pH}>13)$ que, a partir do método original, realiza a eletroforese com o pH alcalino, a qual produz a desnaturação do DNA, e permite a detecção de quebras em ambas: fitas únicas e duplas.

\section{Preparação das lâminas com a primeira solução de agarose LMP}

Foram colocadas duas gotas de agarose low melting point (LMP agarose) a $1,5 \%$ a uma temperatura de $45^{\circ} \mathrm{C}$ sobre a lâmina. Esta agarose deve ser espalhada sobre a lâmina com o auxílio de outra lâmina e deixada secar ao ar livre a temperatura ambiente. Porém, constatou-se que este procedimento é muito demorado e difícil de fixar a agarose na lâmina. Desta forma, optou-se por colocar a solução de agarose derretida em um béquer de $50 \mathrm{ml}$ e mergulhar a lâmina rapidamente, retirando o excesso do produto da parte de baixo da lâminas.

\section{Preparação da suspensão de células das amostras}

Folhas pequenas de cada planta (Figura 1) foram maceradas em um morteiro com 5,0mL de solução tampão fosfato (PBS) acrescido de 1M EDTA. Conforme análise do material macerado e depositado sobre a lâmina, quanto mais macerado melhor visualização dos núcleos da planta (Figura 2). 


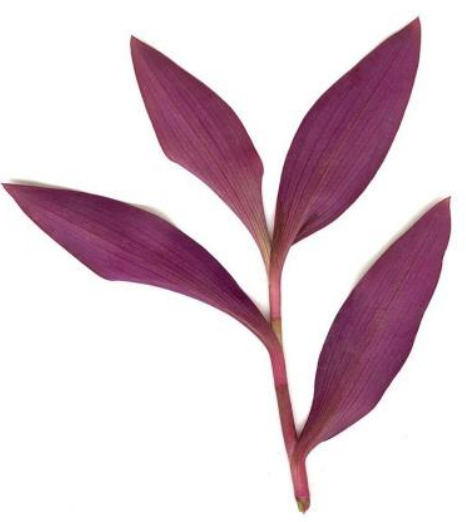

Figuras 1 (a): Amostras de folhas jovens retiradas das plantas foram coletadas e utilizadas para as análises de ensaio cometa. Após lavagem em água corrente, elas foram cortadas em fragmentos quadrados com aprox. $1,0 \mathrm{~cm}$ de lado.

Preparação do gel com células

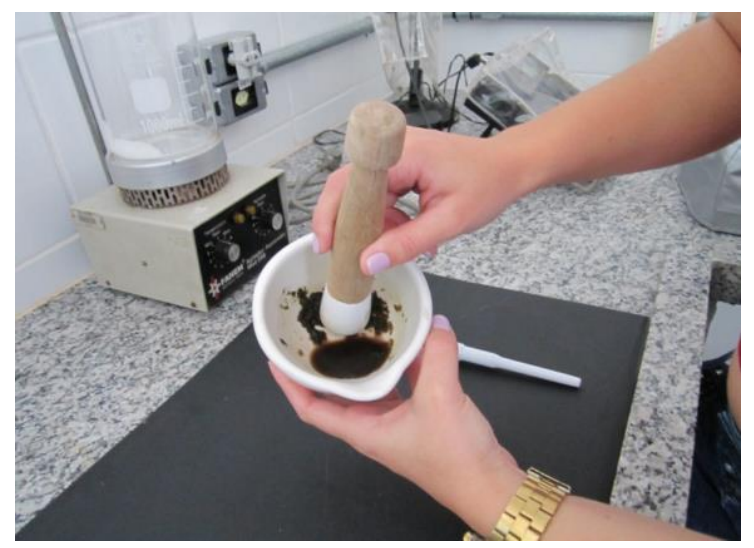

Figura 2: Folhas pequenas são maceradas em um morteiro com $5,0 \mathrm{~mL}$ de solução PBS acrescido de EDTA. As análises sob microscópio ótico revelaram que, quanto mais macerado o material biológico, melhor é a visualização dos núcleos das células vegetais.

Foram misturados um volume de cerca de $90 \mu \mathrm{L}$ da suspensão de células maceradas com $600 \mu \mathrm{L}$ de solução de low melting point agarose $0,8 \%$ a $45^{\circ} \mathrm{C}$. Desta mistura, cerca de $100 \mu \mathrm{L}$ foram rapidamente pipetados sobre uma lâmina contendo a primeira solução de agarose a 1,5\% (Figura 3). Sobre esta lâmina foi colocada uma lamínula evitando a formação de bolhas de ar e colocada na geladeira por 5 minutos para solidificar (Figura 4). Decorridos os 5 minutos, a lamínula foi retirada com cuidado, previamente à etapa de lise das células. Foram preparadas um total de 12 lâminas em cada experimento.

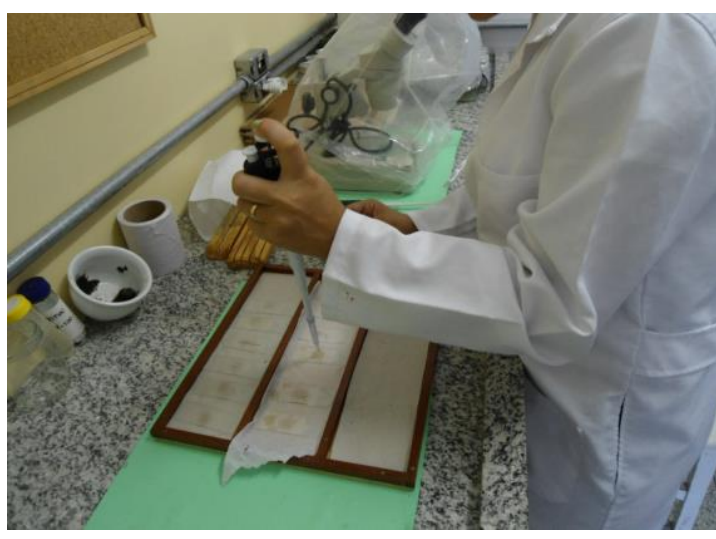

Figura 3: A suspensão de células é misturada com a solução de agarose LMP e rapidamente pipetados sobre uma lâmina, de modo a

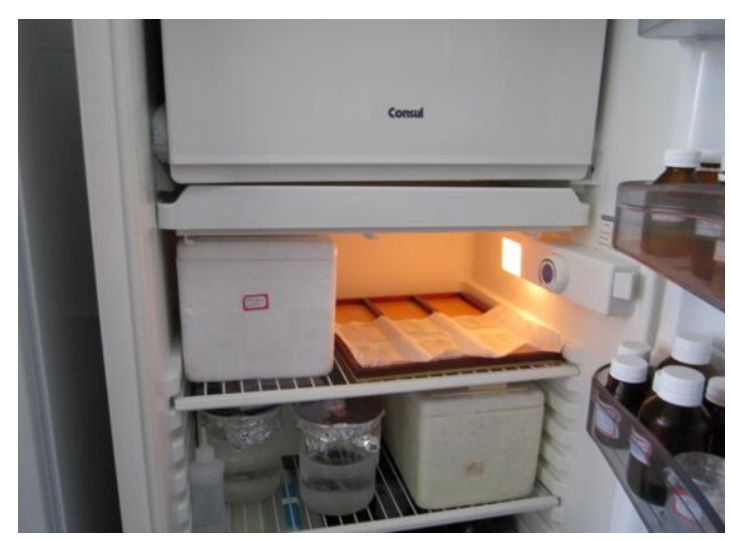

promover a aderência dos núcleos com a segunda camada. 
sódio (SDS) a 2,5\% (p/v) em tampão TBE e incubadas a $4^{\circ}$.C por 1 hora.
Figura 4: As lâminas são imersas em solução de lise contendo solução de dodecil sulfato de Lise das células

As lâminas foram imersas em solução de lise contendo $2,5 \%(p / v)$ de dodecil sulfato de sódio em solução tampão TBE e incubadas na geladeira $\left(4^{\circ} \mathrm{C}\right)$ por 1 hora. Após este tempo de incubação, as lâminas foram enxaguadas com água destilada e lavadas por cerca de 10 minutos. Este passo e todos os demais subsequentes foram conduzidos sob luz fraca para prevenir danos adicionais no DNA.

\section{Desnaturação}

As lâminas foram imersas na solução de desnaturação e incubadas sob agitação lenta por 20 minutos a $4^{\circ} \mathrm{C}$. Como o gel de agarose é muito frágil, no momento que é realizado o tratamento, as lâminas foram imersas na solução de desnaturação e mantidas na geladeira por 15 minutos. Após este tempo foi realizada cuidadosamente a lavagem das laminas.

\section{Eletroforese}

A cuba de eletroforese foi preenchida com a solução de tampão TBE até cobrir totalmente a lâmina contendo o material biológico em análise (Figura 5). $\mathrm{O}$ tempo e as condições de corrida utilizados na presente pesquisa foram, respectivamente, 15 minutos a $23 \mathrm{~V}$ e $22 \mathrm{~mA}$. 


\section{T. Fórum Ambiental}

da Alta Paulista

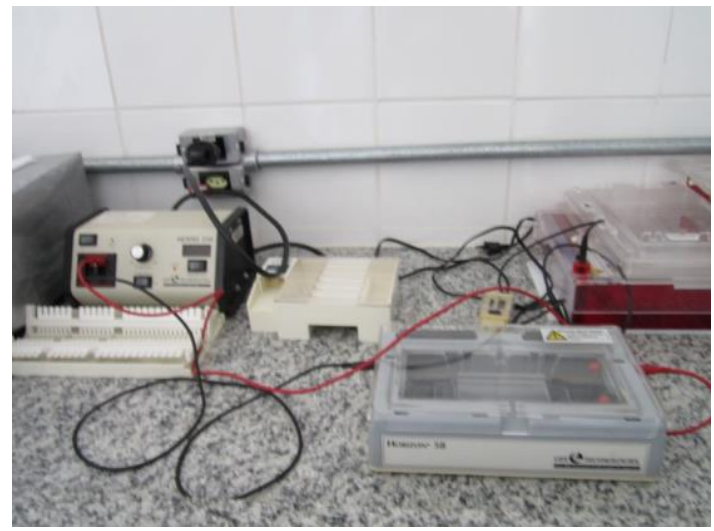

Figura 5: Após preenchimento da cuba de eletroforese com solução tampão TBE a 1\%, as lâminas são colocadas lado a lado e submetidas à corrida por cerca de 10 minutos.

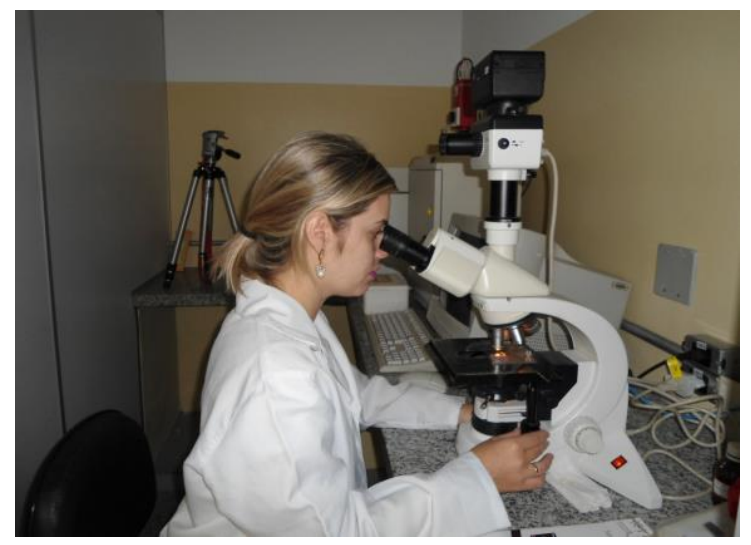

Figura 6: A observação ao microscópio ótico permite identificar as características dos núcleos celulares e a extensão dos danos genéticos provocados pelos mutagênicos.

\section{Coloração}

Entre os testes para avaliar a adequação de outros corantes usualmente empregados em microscopia ótica de campo claro, foi utilizado o corante Giemsa solução a $1 \%$, por 5 minutos e lavados com água destilada. É importante ressaltar que, na hora da lavagem, todas as lâminas apresentaram o desprendimento do gel de agarose de sua superfície. De modo a contornar este problema, foram tomados diversos cuidados, tais como: não inclinar a lâmina durante as lavagens, reduções no tempo de tratamento, redução no volume de solução de Agarose empregada em cada lâmina, entre outros.

\section{Observação ao microscópio ótico}

Após a secagem das lâminas na estufa a $37^{\circ}$ graus, por 10 minutos, foi realizada a leitura das lâminas no microscópio ótico (Figura 6), para verificar se houve a formação de cometas (Figuras 7 e 8). 


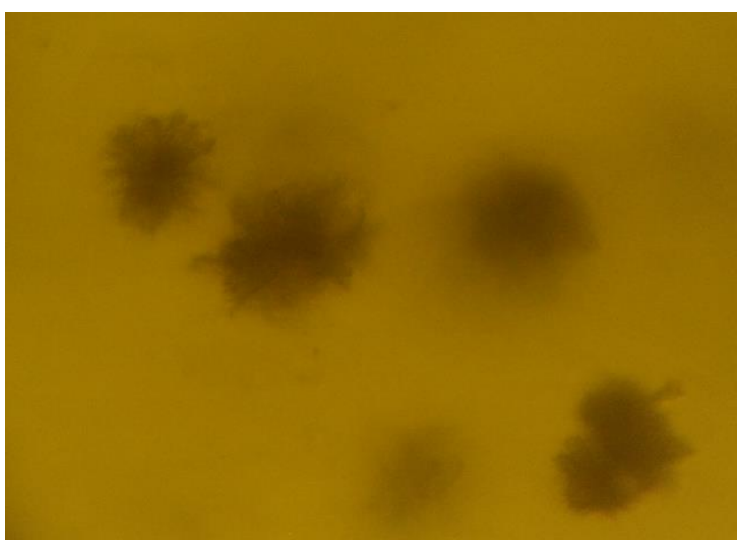

Figura 7. Núcleos celulares de Tradescantia pallida cv. purpurea, corados com solução de Giemsa a 1\%, mostrando os cromossomos aparentemente desprovidos de envoltório nuclear.

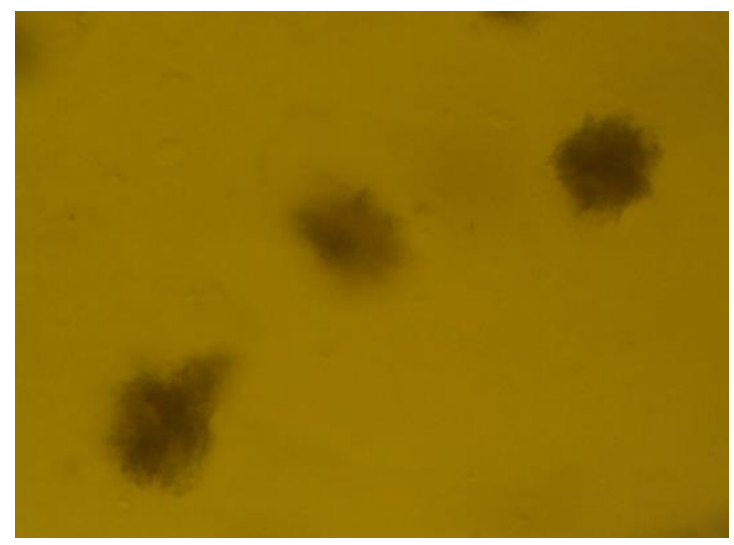

Figura 8. Núcleos celulares de Tradescantia pallida cv. purpurea, corados com solução de Giemsa a 1\%, com formação da "cauda" do cometa nítido ao microscópio ótico.

\section{CONCLUSÕES}

Foi verificado que o primeiro método (versão neutra) produziu os melhores resultados, em função da relativa facilidade em comparação com o método alcalino. Células removidas de folhas das plantas expostas à radiação solar direta permitiram a visualização de extensa ocorrência de danos ao material genético.

A implantação da metodologia e padronização de análise pelo ensaio Cometa abre perspectivas favoráveis para a sua utilização na avaliação do potencial mutagênico de fatores antrópicos. Como exemplo de aplicação da metodologia, pretende-se cultivar plantas desta espécie em situações discrepantes, como resultado das combinações de dois fatores básicos: exposição à radiação solar e exposição ao tráfego de veículos e avaliar o efeito sazonal devido às estações do ano: inverno e verão.

\section{REFERÊNCIAS BIBLIOGRÁFICAS}

ALBERTINI, R.J.; ANDERSON, D.; DOUGLAS, G.R.; HAGMAR, L.; HEMMINKI, K.; MERLO, F.; NATARAJAN, T.A.; NORPPA, H.; SHUKER, D.E.G.; TICE, R.; WATERS, M.D.; AITIO, A. IPCS guidelines for the monitoring of genotoxic effects of carcinogens in humans. Mutation Research, v. 463, p. 111-172, 2000.

ARAÚJO, M.M. Aplicação do método microbiológico DEFT/APC e do teste do cometa na detecção do tratamento com radiação ionizante de hortaliças 
minimamente processdas. 2008. 66 f. Dissertação (Mestre em Ciências) Instituto de Pesquisas Energéticas e Nucleares. São Paulo

BETTI, C.; LOPRIENO, T.D.L.G.; BARALE, R. Microgel electrophoresis assay (Comet test) and SCE analysis in human lymphocytes from 100 normal subjects, Mutation Research, v. 307, p. 323-333, 1994.

BETTI, C.; DAVINI, T.; GIANNESSI, L.; LOPRIENO; N. \& BARALE, R. Comparative studies by comet test and SCE analysis in human lymphocytes from 200 healthy subjects. Mutation Research, v. 343, p. 201-207. 1995.

CERDA, H.; DELLINCEE, H.; HAINE, H.; RUPP, H. The DNA 'comet assay' as a rapid screening technique to control irradiated food. Mutation Research, v. 375, p. 167-181, 1997.

CERDA, H., KOPPEN, G. DNA degradation in chilled fresh chicken studient with the neutral comet assay. Z. Lebensm. Unters. Forsch, v. 207, p. 22-25, 1998.

COTELLE, S.; FÉRARD, J.F. Comet Assay in Genetic Ecotoxicology: A Review. Environmental and Molecular Mutagenesis, v. 34, p. 246- 255. 1999.

DELINCÉE, H. Detection methods for irradiated foodds-an overview. Radical Phsyccs and Chenistry, v. 48, Issue 3, p. 378-379, 1996.

FAIRBAIRN, D.W., OLIVE, P.L.; O'NEILL, K.L. The Comet assay: a comprehensive review. Mutation Research, v. 339, p. 37-59, 1995.

GONTIJO, A.M.M.C.; TICE, R. Teste do cometa para a detecção de dano no DNA e reparo em células individualizadas. In: RIBEIRO, L. R.; SALVADORI, D. M. F.; MARQUES, E. K. (Org.). Mutagênese Ambiental, Canoas: ULBRA, p. 173-200, 2003.

GREEN, M.H.L., LOWE, J.E.; HARCOURT, S.A.; AKINLUYI, P.; ROWE, T.; COLE, J.; ANSTEY, A.V.; ARLETT, C.F. UV-C sensivity of unstimulated and stimulated human lymphocytes form normal and Xeroderma pigment sum donors in the Comet assay: a potencial diagnostic technique. Mutation Research, DNA Repair, v. 273, p. 137- 144, 1992.

KAMMANN, U.; BUNKE, M.; STEINHART, H. A permanent fish cell line (EPC) for genotoxicity testing of marine sediments with the comet assay. Mutation Research, Amsterdam, v. 498, p. 61- 77, 2001.

KAPPEL, B.P. Avaliação do efeito fotoprotetor de três extratos de plantas da Antártica por diferentes modelos biológicos. 2007. 91 f. Dissertação (Mestre em Biologia Molecular e Celular) - Programa de Pós Graduação em Biologia Celular e Molecular. Universidade Federal do Rio Grande do Sul.

KOPPEN, G.; TONCELLI, L.M.; TRIEST, L.; VERSCHAEVE, L. The comet assay: a tool to study alteration of DNA integrity in developing plant leaves. Mech. Ag.Develop, v. 110 (1-2), p. 13-24, 1999. 
LAU, A.H. Avaliação Múltipla do Potencial Genotóxico da Poluição Urbana. 2002. 139f. Tese (Doutor em Ciências) - Genética e biologia molecular. Universidade Federal do Rio Grande do Sul.

MCKELVEY-MARTIN, V.J.; GREEN, M.H.L.; SCHMEZER, P.; POOL-ZOBEL, B.L.; DE MÉO, M.P.; COLLINS, A. (1993). The single cell gel electrophoresis assay (Comet assay): a European review. Mutation Research, v. 288, p. 47-63, 1993.

OSTLING, O.; JOHANSON, K.J. Microelectrophoretic study of radiation-induced DNA damages in individual mammalian cells. Biochem. Biophys. Res. Commun, v. 123, p. 291-298,1984.

PEDRO, J. Detecção da citotoxicidade, genotoxicidade e mutagenicidade, do inseticida fipronil no organismo teste allium cepa. 2008. 117 f. Dissertação (Mestre em Ciências Biológicas) - Instituto de Biociências. Universidade Estadual Paulista, Rio Claro.

ROSS, G.; MCMILLAN, M.T.J.; WILCOX, P.; COLLINS, A.R. The single cell microgel electrophoresis assay (Comet assay): technical aspects and applications, Report On The 5 th Lh Gray Trust Workshop, Institute of cancer research, 1994. Mutation Research, v. 337, p. 57-60, 1995.

SANTOS, I.T.Q.P. Avaliação da atividade clastogênica do resíduo catalítico industrial, por meio do bioensaio de micronúcleos com Tradescantia pallida cv. purpurea. 2004. 114 f. Tese (Doutor em Ciência) - Faculdade de medicina, São Paulo.

SILVA, J. O uso do ensaio cometa para o ensino de genética toxicológica. Genética na escola. Universidade Luterana do Brasil, ISSN 1980-3540, Canoas-RS, p. 30-33, 02 fev, 2007.

SINGH, N.P.; MCCOY, M.T.; TICE, R.R.; SCHENEIDER, A. A simple technique for quantification of low levels of DNA damage in individual cells. Experimental Cell Research, San Diego, 1: 184-191, 1998.

SOUZA, S.A.M. Biotestes na avaliação da fitotoxicidade de extratos aquosos de plantas medicinais nativas do Rio Grande do Sul. 2005. 89 f. Monografia (Bacharel em Ciências Biológicas) - Instituto de Biologia. Universidade Federal de Pelotas.

TICE, R.R. The single cell/gel/ Comet assay: a micro gel electrophoretic technique for the detection of DNA damage and repair in individual cells. In: Environmental Molecular Mutagenesis, Philips, D. H. \& S. Venitt (Eds), Bios Scientific Publishers Ltd, Oxford, U. K., p. 315-339. 1995.

TICE, R.R.; ANDREES, P.; VASQUEZ, M. Protocol for the application of the alkaline single cell gel (SCG) assay to the detection of DNA damage in mammalian cells. In: Integrated Laboratory Systems, p. 1- 8, 1996.

TICE, R.R.; AGURELL, E.; ANERSON, B.; BURLINSON, B.; HARTMANN, A.; KOBAYASHI, H.; MIYAMAE, Y.; ROJAS, E.; RYU, J.C.; SASAKI, Y.F. Single cell 
gel/comet assay: guidelines for in vitro and in vivo genetic toxicology testing. Environmental and. Molecular Mutagenesis, v. 35, p. 206-21, 2000.

VENTURA, B.C. Avaliação dos efeitos citotóxicos, genotóxicos e mutagênicos do herbicida atrazina, utilizando Allium cepa e Oreochromis niloticus como sistemasteste. 2004. 133 f. Dissertação (Mestre de Ciências Biológicas) - Instituto de Biociências, Universidade Estadual Paulista, Rio Claro.

VILLELA, I.V.; OLIVEIRA, I.M.; SILVA, J.; HENRIQUES, J.A. DNA damage and repair in haemolymph cells of golden mussel (Limnoperna fortunei) exposed to environmental contaminants. Mutation Research, v. 605, p. 78-86, 2006. 